А.О. Ічетовкін, інженер ПАТ «ЗОЕ» Запорізькі високовольтні електричні мережі

Д.О. Кулагін, к.т.н, проф. Запорізький національний технічний університ,

В.В. Ніценко, к.т.н., провідний інженер

РДЦ Дніпровського регіону ДП «НЕК «Укренерго»

\title{
ПРОБЛЕМИ ЕКСПЛУАТАЦІЇ ДИФЕРЕНЦЙНОГО СТРУМОВОГО ЗАХИСТУ СИЛОВИХ ТРАНСФОРМАТОРІВ І АВТОТРАНСФОРМАТОРІВ ТА ЗАХОДИ 3 ЇХ ВИРІШЕННЯ
}

\begin{abstract}
У статті розглянуті проблемні питання, які стосуються технічної експлуатаціі сучасних автоматичних пристроїв релейного захисту силових трансформаторів та автотрансформаторів, а зокрема проаналізовані випадки їх неправильної дії в об'єднаній електроенергетичній системі Украӥни, на підставі чого встановлені причини виникнення цих випадків та виявлені недоліки релейного захисту, що призвели до їх виникнення. Встановлено, щуо найбільш поширеними причинами хибної та надлишкової дії захисту є поява кидку струму намагнічування при увімкненні під напругу силового трансформатору, порушення иілісності струмових кіл захисту та помилки, допущені обслуговуючим персоналом при налаштуванні захисту та в процесі його експлуатації. На підставі статистичних даних щзоо роботи релейного захисту трансформаторів протягом останніх 10 років розраховані показники надійності його дії (надійності спраџювання, надійності неспрацювання та загальної надійності), зокрема встановлено, що загальна надійність пристроїв диференційного струмового захисту трансформаторів становить 88,5\%, та запропоновані заходи, щзо спрямовані на підвищення цчих показників.
\end{abstract}

Ключові слова: релейний захист, диференційний струмовий захист трансформатора, трансформатор, автотрансформатор, трансформатор струму, кидок струму намагнічування.

Вступ. Питання, що стосуються забезпечення надійної роботи електричних станцій (ЕС) та енергетичних об'єктів магістральних і розподільчих електричних мереж (ЕМ), є принципово важливими та потребують своєчасного вирішення, адже від цього залежить перш за все їх безаварійна та стійка робота, безперебійність передачі електричної енергії та електропостачання споживачів. Більшість енергетичних компаній приділяють вирішенню цих питань значну увагу, оскільки виникнення та розвиток аварійної ситуації, спричиненої низькою надійністю окремих ділянок (елементів) ЕМ, як правило, супроводжується значними економічними збитками, які несуть вказані компанії. Надійність роботи електроенергетичної системи (ЕЕС) в цілому забезпечується перш за все злагодженою та вчасною дією автоматичних пристроїв релейного захисту (Р3), метою яких $є$ швидке виявлення пошкодженого елементу ЕЕС та його відділення від інших непошкоджених елементів.

У статті розглянуті питання, що стосуються проблеми експлуатації пристроїв Р3 силових трансформаторів та автотрансформаторів (надалі у статті під терміном «силовий трансформатор» слід розуміти також «автотрансформатор»), які позначаються перш за все на надійності їх функціонування, а отже і на надійності електропостачання споживачів, що отримують живлення від підстанційних трансформаторів, надійності електропередачі ЕМ та видачі потужності через блочні трансформатори, встановлені на ЕС. Всі ці проблеми тісно пов'язані із особливостями побудови та функціонування пристроїв Р3 трансформаторів, їх технічної експлуатації та оперативного обслуговування.

У теперішній час у якості комплекту основного швидкодіючого захисту силових трансформаторів від всіх видів їх пошкоджень застосовують пристрої диференційного струмового захисту трансформатору (ДЗТ). Зона дії цих пристроїв обмежується встановленими на стороні кожної обмотки трансформатора трансформаторів струму (ТС), до вторинних кіл яких підключено ДЗТ [1]. Варто відзначити, що ДЗТ забезпечує абсолютно селективний захист трансформаторів з урахуванням нормативних вимог, що висуваються до нього [2]. Принцип дії ДЗТ заснований на визначенні геометричної суми струмів ТС, підключених до зони дії захисту, а також на динамічному гальмуванні його дії, що дозволяє забезпечити пропорційне співвідношення між уставкою диференційного струму спрацювання та величиною гальмівного струму, у якості якого може бути застосований струм одного із ТС, алгебраїчна сума струмів усіх ТС, підключених до зони ДЗТ, або напівсума цих струмів [3]. Більш детальніше особливості побудови та принцип дії реле ДЗТ розглянуті у $[1,3]$. Варто відзначити, що даний тип Р3 трансформатора $є$

(ОА.О. Ічетовкін, Д.О. Кулагін, В.В. Ніценко, 2018 


\section{ISSN 1813-5420 (Print). Енергетика: економіка, технології, екологія. 2018. № 1}

нечутливим до деяких видів його внутрішніх пошкоджень, а саме до тих, що поступово розвиваються та прогресують, такі як міжвиткові замикання в обмотках трансформатора, тому, як правило, на потужних трансформаторах у доповненні до ДЗТ застосовують пристрої газового захисту (ГЗ), що є окремим видом технологічного захисту трансформатора.

На сьогодення на енергетичних об'єктах об'єднаної електроенергетичної системи (ОЕС) України в експлуатації перебувають електромеханічні (типу ДЗТ-11, РНТ-560 та їм подібні), напівпровідникові (типу Д3Т-21, ДЗТ-23) та мікропроцесорні (типу RET670 - ABB, Siprotec 7UT611 - Siemens, Діамант T011, T010 - Хартрон-Інкор та інші) пристрої ДЗТ $[4,5]$. Всі вони мають схожий принцип дії - диференційний струмовий, та відрізняються переважно елементною базою, а також логічними алгоритмами функціонування захисту, при чому мікропроцесорні пристрої, як правило, мають більш досконалі алгоритми та гнучку логіку, більш широкий діапазон регулювання робочих уставок та характеристик. Проте всі ці пристрої об'єднують зафіксовані випадки неправильної дії ДЗТ, що з тих чи інших причин виникли у процесі їх технічної експлуатації на енергетичних об'єктах, а саме: хибне або надлишкове спрацювання захисту або його відмова. Саме аналізу та встановленню основних причин виникнення цих випадків, що вказують на наявність певних недоліків ДЗТ, а також розробці можливих заходів 3 їх усунення, присвячене дане дослідження.

Актуальність роботи. Актуальність дослідження полягає у тому, що пристрої Р3 силових трансформаторів $\epsilon$ відповідальними та функціонально складними, оскільки мають складне налаштування, помилки у якому можуть призводити до порушення їх селективної та надійної дії. Окрім того, значна кількість пристроїв ДЗТ, що перебувають в експлуатації на ЕС та підстанціях (ПС) ОЕС України є технічно застарілими та працюють понад нормативний термін (15-25 років в залежності від елементної бази пристрою), що також є одною із причин зниження їх надійності [6]. Також, як це встановлено із досвіду експлуатації пристроїв ДЗТ, існують певні режими та умови роботи енергосистеми, за яких можлива хибна або надлишкова дія цих пристроїв, що підкреслює недоліки диференційного струмового принципу дії Р3 трансформаторів та вимагає розробки нових більш досконалих алгоритмічних засобів з їх усунення. Аналіз причин випадків неправильної дії пристроїв ДЗТ є актуальним завданням, що потребує комплексного вирішення з метою підвищення надійності захисту та створення умов для його селективної дії за будь-яких режимів ЕЕС та забезпечення належних умов експлуатації захисту.

Мета роботи - визначення основних проблемних питань, пов'язаних з експлуатацією пристроїв диференційного струмового захисту силових трансформаторів, та встановлення причин їх неправильної роботи 3 метою оцінки показників надійності захисту та виявлення недоліків цих пристроїв, а також розробки заходів щодо їх перспективного вирішення.

\section{Матеріали і результати досліджень.}

Авторами були проаналізовані випадки неправильної дії пристроїв ДЗТ, що мали місце за їх експлуатації на енергетичних об'єктах ОЕС України протягом останніх 10 років згідно річної звітності державної енергетичної компанії «Укренерго», на підставі чого встановлені основні причини їх виникнення та виявлені недоліки (конструктивні, алгоритмічні, налаштування, експлуатаціі), що призвели до неправильної дії цих пристроїв.

Зокрема, відповідно до звітності щодо роботи пристроїв РЗ на ЕС та ПС з вищою напругою 330-750 кВ ОЕС України, було встановлено, що надлишкова або хибна дія ДЗТ переважно фіксувалась за наступних режимів ЕЕС та умов експлуатації захисту:

- аперіодичний (однополярний) та періодичний кидок струму намагнічування при увімкненні під напругу ненавантаженого силового трансформатора (під час виконання оперативних перемикань);

- насичення ТС, до вторинних кіл яких підключено захист;

- порушення цілісності струмових кіл захисту (виникнення обриву, замикання на землю через пробій ізоляції кабелю, шунтування окремих кіл тощо);

- перехідні режими зовнішнього короткого замикання (КЗ) зі значним вмістом аперіодичної складової первинного струму та значної амплітудою (кратністю) струму КЗ;

- технічна несправність пристрою ДЗТ або ТС, до вторинних кіл яких підключено захист (пошкодження диференційного реле, наявність виткових замикань у вторинній обмотці ТС);

- порушення вимог до технічної експлуатації та оперативного обслуговування пристроїв ДЗТ (помилки, що допущені обслуговуючим персоналом);

- зовнішні КЗ зі значною кратністю аварійного струму, високими похибками ТС, що призводять до появи суттєвого за величиною струму небалансу у диференційному колі ДЗТ.

Окремо заслуговує уваги одне із вживаних релейним персоналом формулювань при описі технологічного порушення, що супроводжувалось хибною дією ДЗТ: «Аналіз осцилограми аварійного процесу в момент відключення трансформатору дією ДЗТ показав, що параметри кидку струму 
намагнічування у момент увімкнення трансформатора перевищили розрахункові норми на відлаштування захисту від аперіодичного струму намагнічування, які закладені розробниками та виробниками захисту, що, як наслідок, призвело до його спрацювання».

Таке формулювання безпосередньо вказує на те, що ДЗТ має деякі недоліки, допущені розробником, яким зокрема не було враховано у розроблених конструктивних вузлах диференційного реле, його алгоритмах або методиках налаштування ймовірності виникнення описаного режиму 3 електричними параметрами кидку струму намагнічування, що перевищили нормовані показники. Осцилограми процесів увімкнення силового трансформатора під напругу з хибним спрацюванням його диференційного захисту, що отримані $з$ цифрового реєстратору «РЕКОН» показані на рис. 1.

Як видно із рис.1, трьохфазний кидок струму намагнічування має однополярний характер у фазах «B» і «С» та періодичний характер у фазі «А», що переважно залежить від моменту увімкнення трансформатору під напругу, а саме від значення початкової фази напруги живильної ЕМ. При цьому форма періодичного струму у фазі «А» $є$ спотвореною та, подібно до аперіодичних струмів у інших двох фазах, має безструмові паузи шириною до 2-3 мс. Зліва на осцилограмах зазначені діючі значення струму намагнічування у кожній фазі, зокрема на рис. 16 у фазі «С» його діюче значення перевищує 1 кА, що $\epsilon$ достатньо суттєвою величиною враховуючи той факт, що уставка диференційного реле з гальмуванням

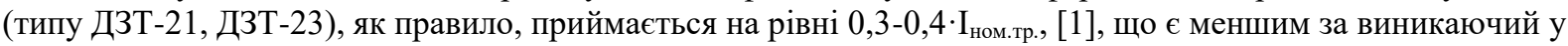
диференційному колі небаланс струмів (диференційний струм), спричинений кидком струму намагнічування в обмотці високої напруги силового трансформатора. На останньому дискретному каналі реєстратору, як бачимо із рис. 1, зафіксовано сигнал, який свідчить про хибне спрацювання ДЗТ, причому на рис. $1 б$ хибне спрацювання здійснюється вже на третьому періоді з моменту виникнення кидку струму.

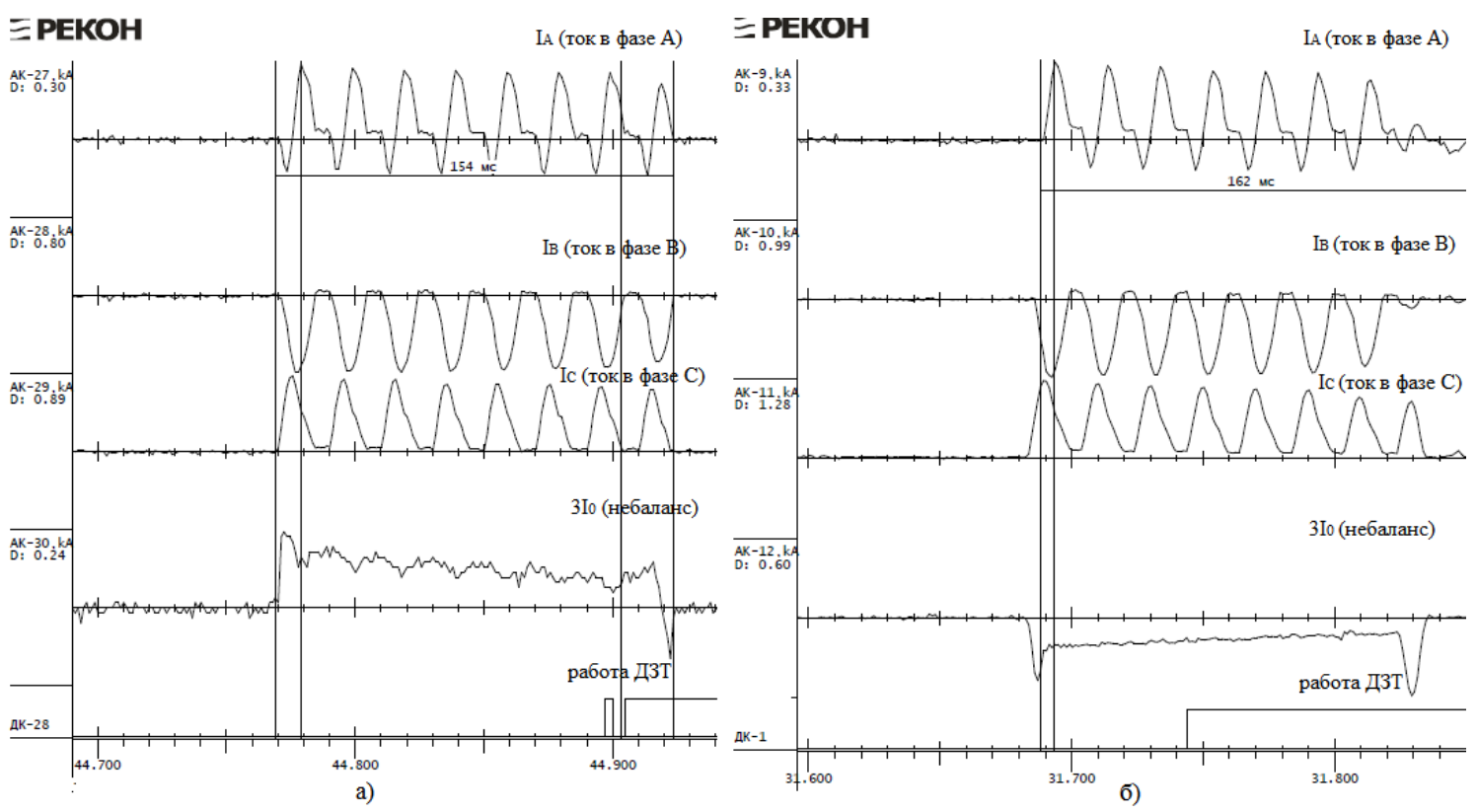

Рисунок 1 - Осцилограми процесів кидку струму намагнічування при увімкненні під напругу силового трансформатора, що супроводжувались хибною дією реле ДЗТ-21: а - хибна дія захисту автотрансформатора на ПС 330 кВ; б - хибна дія захисту блочного трансформатора на ЕС

3 аналізу вищенаведених осцилограм випливає те, що ДЗТ реагує на появу кидку струму намагнічування, а отже має бути надійно відлаштований від хибного спрацювання за цих умов, причому повинні враховуватись всі можливі варіанти спотвореної форми кривої струму намагнічування та граничний діапазон зміни його електричних параметрів. У розглянутих випадках, незважаючи на застосування у ДЗТ спеціальної схеми (алгоритму) блокування, заснованій на часово-імпульсному принципі дії та гальмування за 2-ю гармонікою [3], хибного спрацювання захисту уникнути не вдалось.

Проаналізувавши всі зафіксовані випадки неправильної дії ДЗТ в ОЕС протягом останніх 10 років авторами встановлено, що найбільш поширеними причинами їх виникнення можна вважати наступні:

- низька ефективність існуючих засобів 3 відлаштування захисту від кидку струму намагнічування, що має однополярний та періодичних характер;

- помилки обслуговуючого персоналу, а саме: неправильне налаштування диференційних реле ДЗТ (помилковий вибір або налаштування уставок, помилки у конфігурації внутрішньої логіки мікропроцесорних пристроїв), помилки в процесі їх технічного або оперативного обслуговування; 


\section{ISSN 1813-5420 (Print). Енергетика: економіка, технології, екологія. 2018. № 1}

- порушення цілісності струмових кіл захисту та неефективність вжитих заходів із попередження його хибного спрацювання за цих умов;

- недостатньо висока ефективність застосування алгоритму динамічного гальмування захисту за перехідних режимів зовнішніх КЗ зі значною кратністю аварійного струму, а також у режимах, які супроводжуються насиченням магнітних систем ТС.

Окрім того, причиною неправильної дії ДЗТ може виявитись технічна несправність самого пристрою або ж, як це зазначається у деяких формулюваннях до опису технологічних порушень, неправильне спрацювання ДЗТ виникло 3 «нез'ясованої причини». Проте здебільшого нез'ясована причина $\epsilon$ наслідком порушення персоналом вимог до технічної експлуатації ДЗТ або ж його неправильного налаштування, рідше $\epsilon$ наслідком прихованого дефекту диференційного реле, не виявленого під час його планових перевірок.

Всі вищеперелічені причини, згідно проведеного аналізу, призводять до виникнення надлишкової або хибної дії пристроїв ДЗТ за відсутності вимоги до спрацювання або ж до його відмови у спрацюванні за наявності такої вимоги.

Статистика розподілу проаналізованих випадків неправильної дії пристроїв ДЗТ на енергетичних об'єктах ОЕС України протягом останніх 10 років в залежності від причин їх виникнення зведена до табл. 1. Загальна кількість спрацювання (та неспрацювання при внутрішніх КЗ) ДЗТ становила 218 випадків, 3 них - 193 випадків правильної дії (88,5\%) та 25 випадків неправильної дії (11,5\%).

Таблиця 1 - Статистика розподілу випадків неправильної дії пристроїв ДЗТ на енергетичних об'єктах ОЕС України протягом останніх 10 років.

\begin{tabular}{|c|c|c|c|c|c|c|c|c|c|c|c|c|}
\hline \multirow[t]{3}{*}{ Причина неправильної дії ДЗТ } & \multicolumn{4}{|c|}{ електромеханічні } & \multicolumn{4}{|c|}{ мікроелектронні } & \multicolumn{4}{|c|}{ мікропроцесорні } \\
\hline & \multicolumn{2}{|c|}{$\begin{array}{c}\text { Хибне та } \\
\text { надлишкове } \\
\text { спрацювання }\end{array}$} & \multicolumn{2}{|c|}{$\begin{array}{l}\text { Відмов } \\
\quad \text { a }\end{array}$} & \multicolumn{2}{|c|}{$\begin{array}{c}\text { Хибне та } \\
\text { надлишкове } \\
\text { спрацювання }\end{array}$} & \multicolumn{2}{|c|}{ Відмова } & \multicolumn{2}{|c|}{$\begin{array}{c}\text { Хибне та } \\
\text { надлишкове } \\
\text { спрацювання }\end{array}$} & \multicolumn{2}{|c|}{ Відмова } \\
\hline & шт & $\%$ & шт & $\%$ & шт & $\%$ & шт & $\%$ & шт & $\%$ & шт & $\%$ \\
\hline $\begin{array}{l}\text { 1. Спрацювання від кидку струму } \\
\text { намагнічування }\end{array}$ & 4 & 16 & - & - & 1 & 4 & - & - & 1 & 4 & - & - \\
\hline $\begin{array}{l}\text { 2. Помилки персоналу при } \\
\text { налаштуванні або обслуговуванні } \\
\text { ДЗТ }\end{array}$ & 2 & 8 & - & - & 1 & 4 & - & - & 1 & 4 & 1 & 4 \\
\hline $\begin{array}{l}\text { 3. Порушення цілісності струмових } \\
\text { кіл захисту }\end{array}$ & 4 & 16 & - & - & 2 & 8 & - & - & - & - & - & - \\
\hline $\begin{array}{l}\text { 4. Спрацювання від підвищеного } \\
\text { рівня струму небалансу у } \\
\text { диференційному колі ДЗТ за } \\
\text { перехідних режимів зовнішніх КЗ } \\
\text { або за насичення ТС } \\
\text { (неефективність алгоритму } \\
\text { гальмування) }\end{array}$ & 1 & 4 & - & - & 1 & 4 & - & - & 1 & 4 & - & - \\
\hline $\begin{array}{l}\text { 5. Технічна несправність } \\
\text { диференційного реле ДЗТ }\end{array}$ & 1 & 4 & 1 & 4 & - & - & - & - & - & - & - & - \\
\hline 6. Нез'ясована причина & - & - & - & - & 1 & 4 & - & - & 2 & 8 & - & - \\
\hline PA30M: & 12 & 48 & 1 & 4 & 6 & 24 & - & - & 5 & 20 & $\mathbf{1}$ & 4 \\
\hline
\end{tabular}

За табличними даними була побудована стовбчаста діаграма розподілу випадків неправильної дії пристроїв ДЗТ в залежності від встановлених причин їх виникнення (рис. 2), яка забезпечує більш наочний вигляд отриманих результатів. 


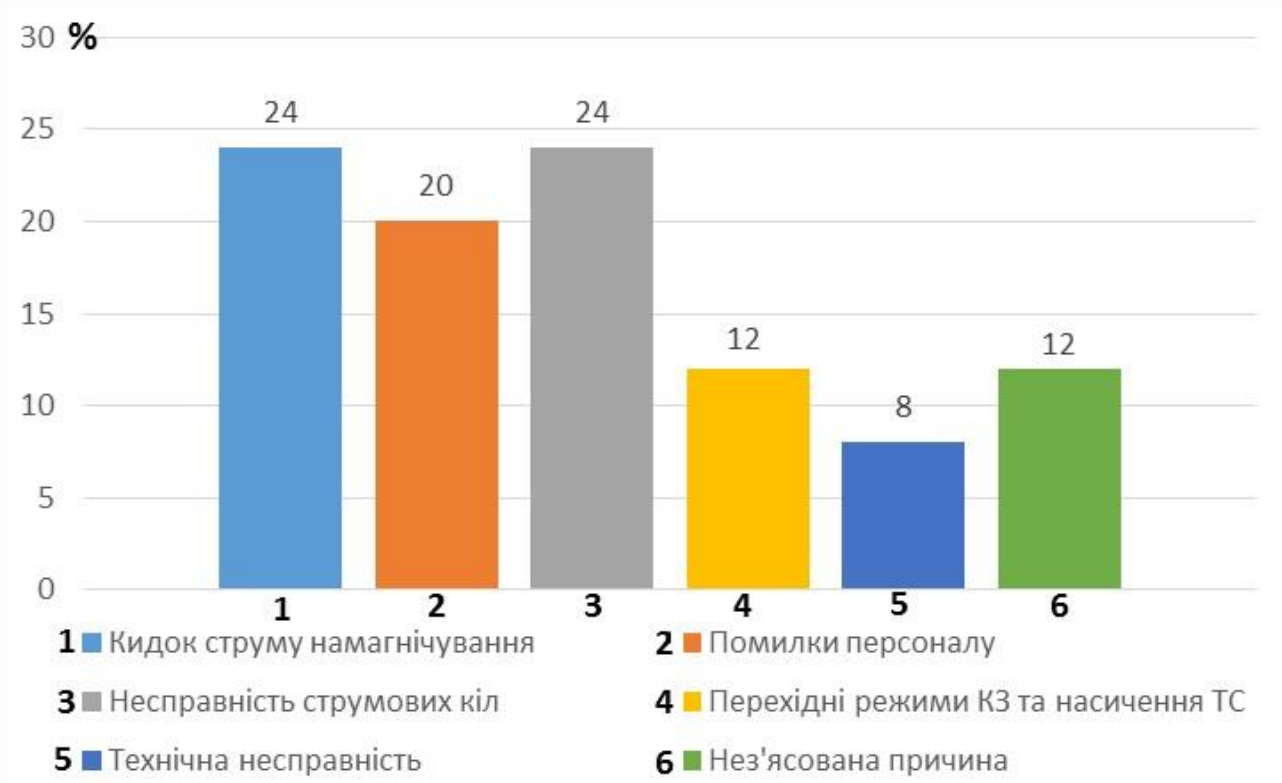

Рисунок 2 - Ілюстрація розподілу випадків неправильної дії пристроїв ДЗТ в залежності від встановлених причин їх виникнення

Як видно із рис. 2, виникнення переважної більшості випадків неправильної роботи пристроїв ДЗТ пов'язана з хибною дією захисту за кидку струму намагнічування силового трансформатору (24\%), його хибною дією за порушення цілісності струмових кіл (24\%) та через помилки персоналу при налаштуванні робочих уставок (характеристик) ДЗТ або його обслуговуванні (20\%). Відносна кількість випадків неправильної дії ДЗТ, що сталися з інших причин є дещо меншою, проте ці випадки також потребують приділення уваги.

На рис. 3 та на рис. 4 показані діаграми, що відображають розподіл випадків хибної (надлишкової) дії та відмови спрацювання відповідно пристроїв ДЗТ, виконаних на електромеханічній, мікроелектронній та мікропроцесорній базі, згідно аналітичних даних, наведених у табл. 1.

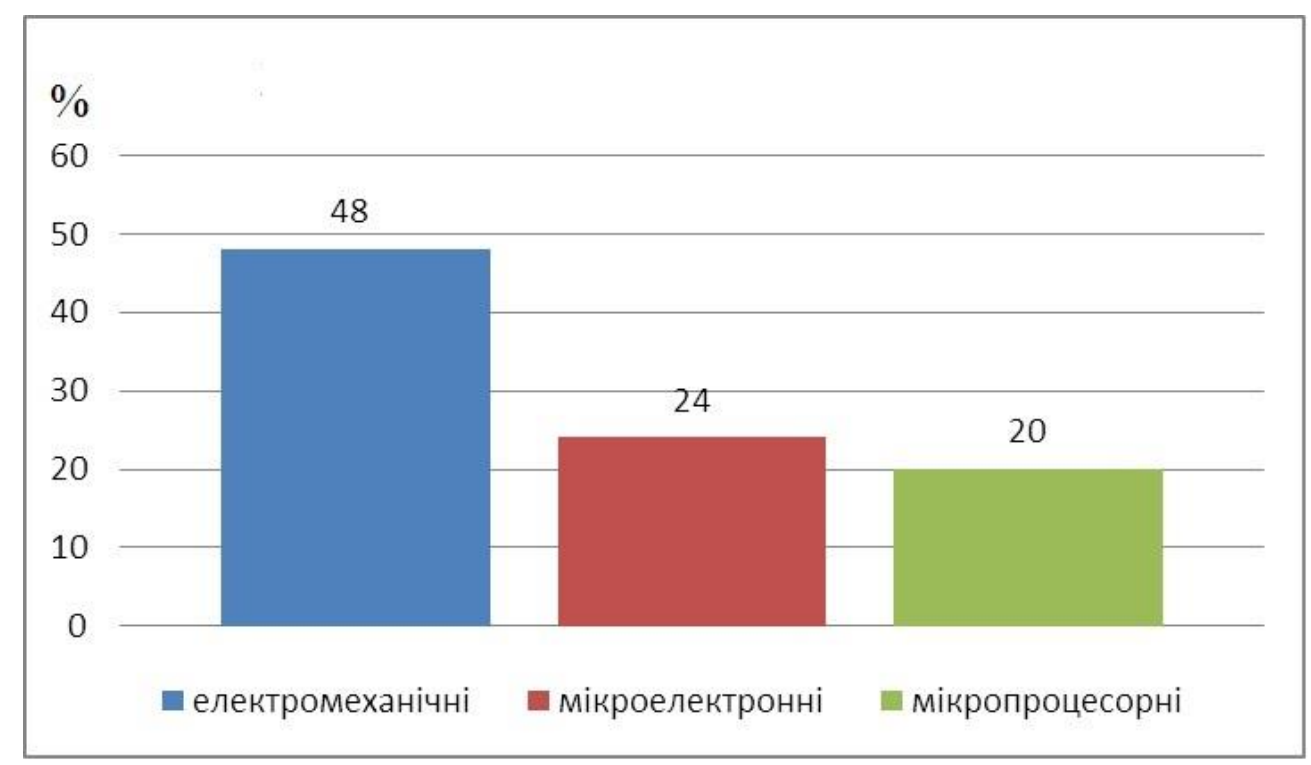

Рисунок 3 - Ілюстрація розподілу випадків хибної (надлишкової) дії пристроїв ДЗТ в залежності від елементної бази 


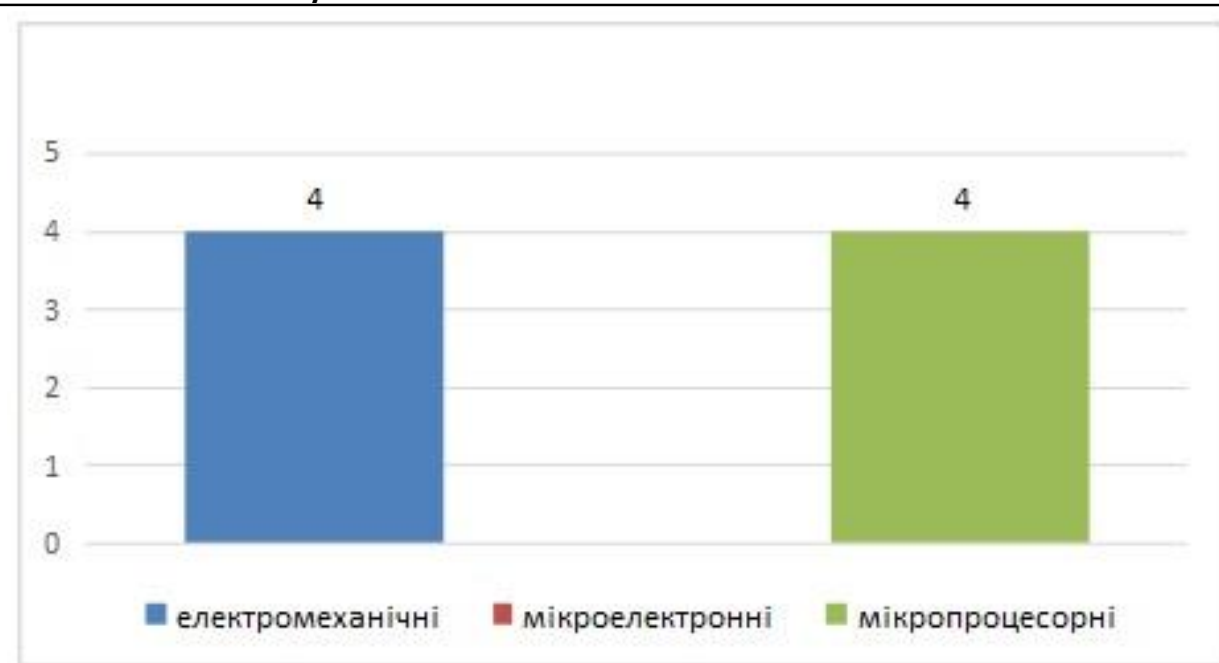

Рисунок 4 - Ілюстрація розподілу випадків відмови дії пристроїв ДЗТ в залежності від елементної бази

3 вищенаведених ілюстрацій можна зробити висновок, що відповідно до статистики, найбільш схильними до надлишкової або хибної дії є пристрої дЗТ, виконані саме на електромеханічній базі - 48\% випадків, що у 2-2,5 рази перевищує аналогічний показник для мікроелектронних та мікропроцесорних ДЗТ). Це насамперед може бути пов'язано з простотою виконання цих пристроїв та відсутністю досконалих технічних рішень щодо їх відлаштування від диференційного струму небалансу у вторинних колах захисту під час зовнішніх К3 (4\%), порушенні цілісності струмових кіл захисту (16\%) та аперіодичному кидку струму намагнічування (16\%). Випадки відмови ДЗТ у спрацюванні були зафіксовані для електромеханічних (4\%) та мікропроцесорних (4\%) Д3Т, що виникли переважно через технічну несправність пристрою Р3 або через помилки персоналу, допущені під час налагодження ДЗТ та у процесі його технічної експлуатації.

У закордонній практиці надійність роботи будь-якого типу Р3, відповідно до [7], може бути оцінена системою із трьох основних показників:

- надійність захисту на спрацюювання (Dependability), D:

$$
D=\frac{N_{C}}{N_{C}+N_{F}},
$$

де $\mathrm{N}_{\mathrm{C}}$ - загальна кількість правильних спрацювань захисту за період спостережень;

$\mathrm{N}_{\mathrm{F}}$ - кількість випадків відмови захисту у спрацюванні за період спостережень;

- надійність захисту на неспрацювання (Security), S:

$$
S=\frac{N_{C}}{N_{C}+N_{U}},
$$

де $\mathrm{N}_{\mathrm{U}}$ - кількість випадків помилкової (надлишкової або хибної) дії захисту за період спостережень; - загальна надійність захисту (Reliability), R:

$$
R=\frac{N_{C}}{N_{C}+N_{U}+N_{F}} .
$$

Вищеперелічені показники можуть бути чисельно визначені на підставі аналізу статистичних даних щодо зафіксованих випадків правильної та неправильної дії пристроїв Р3.

Показник надійності на спрацювання D вказує на загальний відсоток випадків спрацювання Р3 за наявності відповідної вимоги до його спрацювання, в даному випадку для ДЗТ значення даного показнику $\epsilon$ наступним:

$$
D=\frac{193}{193+2} \cdot 100=98,9 \%
$$


Показник надійності на неспрацювання $\mathrm{S}$ характеризує відносну кількість випадків неспрацювання Р3 за відсутності відповідної вимоги до його спрацювання, який для ДЗТ є наступним:

$$
S=\frac{193}{193+23} \cdot 100=89,3 \% .
$$

Показник загальної надійності захисту $\mathrm{R}$ характеризує відносну кількість його правильних спрацювань за період спостережень та для ДЗТ визначається наступним чином:

$$
R=\frac{193}{193+23+2} \cdot 100=88,5 \% .
$$

Як бачимо із проведених розрахунків, показник загальної надійності ДЗТ, відповідно до статистичних даних його експлуатації протягом останніх 10 років, становить лише $88,5 \%$, що $є$ недостатньо високим його значенням [9] та потребує вирішення окремих проблемних питань із усунення недоліків, характерних пристроям ДЗТ, та, як наслідок, підвищення показнику загальної надійності захисту до рівня $95 \%$ та більше.

Нижче у табл. 2 наведені розраховані показники надійності окремо для електромеханічних, мікроелектронних та мікропроцесорних ДЗТ на підставі узагальнених статистичних даних з табл. 1.

\begin{tabular}{|c|c|c|c|c|c|c|}
\hline Апаратна база & $\mathbf{N}_{\mathrm{C}}$, WT & $\mathbf{N F}_{\mathrm{F}}$, ITT & $\mathbf{N U}_{\mathrm{U}}$, IIT & $\mathrm{D}, \%$ & $\mathrm{~S}, \%$ & $\mathrm{R}, \%$ \\
\hline Електромеханічна & 58 & 1 & 12 & 98,31 & 82,86 & 81,69 \\
\hline Мікроелектронна & 111 & 0 & 6 & 100,00 & 94,87 & 94,87 \\
\hline Мікропроцесорна & 24 & 1 & 5 & 96,00 & 82,76 & 80,00 \\
\hline PA3OM: & 193 & 2 & 23 & 98,97 & 89,35 & 88,53 \\
\hline
\end{tabular}

Таблиця 2 - Визначення показників надійності ДЗТ, виконаних на різній апаратній базі

Згідно узагальнених статистичних даних, як бачимо із табл. 2, найбільш надійними виявляються пристрої ДЗТ на мікроелектронній базі, що ймовірно обумовлено набутим суттєвим досвідом експлуатації саме цих пристроїв Р3 силових трансформаторів (автотрансформаторів). Мікропроцесорні пристрої ДЗТ почали впроваджувати відносно нещодавно на підстанціях ОЕС України, тому на сьогодення відбувається поступове набуття досвіду їх налаштування і обслуговування, а саме тому недостатньо висока надійність дії цих пристроїв наразі обумовлена ймовірністю помилок, допущених обслуговуючим персоналом при роботі з ними. Електромеханічні захисти, як це було відзначено, $є$ недосконалими з технічної точки зору, що, перш за все, позначається на надійності їх функціонування.

У зв'язку з цим варто виділити основні недоліки, характерні сучасним пристроям ДЗТ, на вирішенні яких необхідно сконцентрувати увагу при розробці заходів із підвищення надійності функціонування захисту. Проаналізувавши основні причини неправильної дії пристроїв ДЗТ можна виділити їх наступні недоліки:

- не достатня ефективність диференційного струмового методу захисту силових трансформаторів, зокрема алгоритму динамічного гальмування ДЗТ за наступних режимів EEC: кидок струму намагнічування (аперіодичний та періодичний), зовнішні КЗ зі значною амплітудою аперіодичної складової аварійного струму та насичення ТС;

- недосконалість методів контролю цілісності струмових кіл та попередження хибної дії захисту шляхом своєчасного виявлення пошкодження у цих колах;

- недосконалість та складність відомих методик із вибору та налаштування параметричних уставок пристроїв ДЗТ та їх обслуговування, складність конструкції напівпровідникових диференційних реле 3 гальмуванням та робочих алгоритмів мікропроцесорних ДЗТ, місткий набір уставок, які необхідно обрати для забезпечення правильної роботи мікропроцесорного захисту, багато із яких мають рекомендаційний характер, тобто $є$ рекомендованими розробником без будь-яких додаткових обгрунтувань їх значення;

Перші два недоліки $є$ характерними переважно для пристроїв ДЗТ, виконаних на електромеханічній та напівпровідниковій базі, а останній - для мікропроцесорних пристроїв ДЗТ. Це зокрема пов'язано з тим, що сучасні мікропроцесорні пристрої ДЗТ мають більш досконалі та гнучкі алгоритми, які забезпечують абсолютно селективну дію за найбільш несприятливих для ДЗТ режимів ЕЕС, проте основним їх недоліком є складність налаштування та конфігурування цих алгоритмів, що може стати причиною неправильної дії захисту через допущені персоналом помилки. 


\section{ISSN 1813-5420 (Print). Енергетика: економіка, технології, екологія. 2018. № 1}

Таким чином, проаналізувавши вищеперелічені недоліки ДзТ можна запропонувати наступні заходи щзодо ӥх усунення:

- розробка нових та вдосконалення відомих методів, а також розробка більш досконалих алгоритмів P3 силових трансформаторів, що забезпечуватимуть вищі показники надійності захисту, розрахунок яких наведений у статті, та його селективну дію за кидку струму намагнічування, за перехідних процесів КЗ зі значним вмістом аперіодичної складової та у разі насичення ТС;

- вдосконалення та спрощення сучасних методик з налаштування та обслуговування пристроїв ДЗТ, а також доповнення існуючих розрахункових методик, які повинні враховувати більш широкий діапазон зміни електричних параметрів в аварійних режимах роботи трансформатора та за інших порушень нормального режиму його роботи, наприклад у разі виникнення кидку струму намагнічування;

- впровадження надійних засобів з діагностики цілісності струмових кіл РЗ трансформаторів, які забезпечуватимуть своєчасне виявлення їх пошкодження (обриву або замикання однієї або декількох фаз) та швидке блокування ймовірної хибної дії захисту за цих умов;

- розробка більш досконалих та надійних засобів, завдяки застосуванню яких буде вчасно попереджатись ймовірна неселективна дія захисту за підвищеного рівня струму небалансу, що 3 тих чи інших причин може виникнути у диференційному колі, не призводячи при цьому до зменшення чутливості дії захисту при внутрішніх К3.

Висновки. На підставі дослідження статистичних даних експлуатації пристроїв ДЗТ на енергетичних об'єктах ОЕС України протягом останніх 10 років встановлено, що даний тип РЗ силових трансформаторів має певні недоліки, здатні призводити за певних умов та режимів ЕЕС до неправильної дії захисту, наслідком якої може бути безпідставне знеструмлення окремих споживачів, перевантаження інших елементів ЕЕС тощо. Встановлено, що показник загальної надійності ДЗТ за період спостережень (10 років) становить близько 88,5\%, при цьому із 25 зафіксованих випадків неправильної дії захисту переважну більшість становлять випадки його надлишкової або хибної дії і лише 2 випадки його відмови, що свідчить загалом про достатню чутливість захисту до внутрішніх КЗ та його високу готовність до спрацювання у разі пошкодження трансформатора, що захищається. Однак все ж таки зафіксовані 23 випадки неселективної дії пристроїв ДЗТ (без пошкодження трансформатора) на ЕС та системних ПС $є$ достатньо високим показником, який спонукає до розробки нових заходів, спрямованих на попередження виникнення подібних випадків у майбутньому.

\section{Список використаної літератури}

1. Киреева Э. Р. Релейная защита и автоматика электроэнергетических систем / Э. Р. Киреева. - М. : Академия, 2014. - 287 с.

2. Правила улаштування електроустановок : Глава 3.2. Релейний захист / Мінпаливенерго України. - К. : НПЦР, 2015. - 88 c. 549 c.

3. Шнеерсон Э. М. Цифровая релейная защита / Э. М. Шнеерсон. - М. : Энергоатомиздат, 2007. -

4. Busbar protection RET670. Application manual : 1MRK 505 211-UEN. - Baden : ABB Switzerland Ltd, 2012. -447 p.

5. Siprotec 5 busbar protection 7UT611. Manual : C53000-G5040-C019. - Munich : Siemens AG, 2014. $-532 \mathrm{p}$.

6. Технічне обслуговування мікропроцесорних пристроїв релейного захисту, протиаварійної автоматики, електроавтоматики, дистанційного керування та сигналізації електростанцій і підстанцій від 0,4 кВ до 750 кВ : СОУ-Н-ЕЕ 35.514:2007. — [Чинний від 2007-10-30]. — К. : ОЕП «ГРІФРЕ», 2008. — 79 с. - (Національні стандарти України).

7. Gurevich V. Microprocessor protection relays: new prospects or new problems? / V. Gurevich // Electrotekhnika i Electromekhanika. - 2006. - vol. 3. - P. 18-26.

8. Рубинчик В. А. Резервирование отключения коротких замыканий в электрических сетях / В. А. Рубинчик. - М. : Энергоатомиздат, 1985. - 180 с. 
А.А. Ичетовкин, инженер ПАО «ЗОЭ» Запорожские высоковольтные электрические сети

Д.А. Кулагин, к.т.н, профессор Запорожский национальный технический университет,

В.В. Ниценко, к.т.н., ведущий инженер РДЦ Днепровский регион ГП «НЭК «Укрэнерго»

\section{ПРОБЛЕМЫ ЭКСПЛУАТАЦИИ ДИФФЕРЕНЦИАЛЬНОЙ ТОКОВОЙ ЗАЩИТЫ СИЛОВЫХ ТРАНСФОРМАТОРОВ И АВТОТРАНСФОРМАТОРОВ И МЕРОПРИЯТИЯ ПО ИХ РЕШЕНИЮ}

В статье рассмотрены проблемные вопросы, касающиеся технической эксплуатации современных автоматических устройств релейной защиты силовых трансформаторов и автотрансформаторов, а в частности проанализированы случаи их неправильного действия в объединенной электроэнергетической системе Украины, на основании чего установлень причины возникновения этих случаев и выявлены недостатки релейной защзиты, которые привели к их возникновению. Установлено, что наиболее распространенными причинами ложной и излишней работы защиты является появление броска тока намагничивания при включении под напряжение силового трансформатора, нарушение иелостности токовых ичепей защчты и ошибки, допущенные обслужсиваючим персоналом при настройке защиты и в процессе ее эксплуатации. На основании статистических данных о работе релейной защиты трансформаторов на протяжении последних 10 лет рассчитаны показатели надежности ее действия (надежность срабатывания, надежность несрабатывания и общая надежность), в частности установлено, что общая надежность устройств дифференциальной токовой защиты трансформаторов составляет 88,5\%, и предложены мероприятия, направленные на повышение этих показателей.

Ключевые слова: релейная защита, дифференциальная токовая защита трансформатора, трансформатор, автотрансформатор, трансформатор тока, бросок тока намагничивания.

A. Ichetovkin, engineer in PJSK «ZOE» Zaporozhye high-voltage power networks D. Kulagin Cand. Sc. (Eng), Prof., Zaporizhzhya national technical University V. Nitsenko, Cand. Sc. (Eng), lead engineer RDC Dnipro region SI "NEC" Ukrenergo" PROBLEMS IN OPERATION OF TRANSFORMER DIFFERENTIAL PROTECTION RELAYS AND ACTIVITIES FOR THEIR SOLUTION

The article deals with the issues related to operation of modern transformer protection relays, especially, the cases of their false tripping in the electric power system of Ukraine. Cases of false tripping were analyzed to explore disadvantages of transformer protection relays. It was identified that the most common causes of false tripping of protection relays are: magnetizing inrush current, damage of secondary current circuits and errors committed by the maintenance personnel during setting and operation. Based on the statistical data of the protection relays operation over the past 10 years, the reliability of it work was calculated. The overall reliability of transformer differential protection relays is $88.5 \%$ In this work the actions aimed to improve these indicators are advised.

Keywords: protection relays, differential transformer relay, transformer, autotransformer, current transformer, magnetizing inrush current. 